\title{
Using Hirvela's Reading/Writing Connections as a Tool for the Evaluation of Academic Writing Courses
}

\author{
John Harper \\ Language and Culture Center, Duke Kunshan University, Kunshan, China \\ Email: john.harper@dukekunshan.edu.cn
}

How to cite this paper: Harper, J. (2021). Using Hirvela's Reading/Writing Connections as a Tool for the Evaluation of Academic Writing Courses. Open Journal of Modern Linguistics, 11, 424-439. https://doi.org/10.4236/ojml.2021.113032

Received: May 25, 2021

Accepted: June 20, 2021

Published: June 23, 2021

Copyright (อ 2021 by author(s) and Scientific Research Publishing Inc. This work is licensed under the Creative Commons Attribution International License (CC BY 4.0).

http://creativecommons.org/licenses/by/4.0/

\section{(c) (i) Open Access}

\begin{abstract}
This article reports on a study aimed at the implementation of a tool for the evaluation of academic writing courses for second language writers (L2 writers). Specifically, the main principles of the text Connecting Reading and Writing in Second Language Instruction (Hirvela, 2016) are implemented in the evaluation of a previously designed academic writing course in the English Language Center (ELC) of Shantou University (STU), a key provincial university located in Guangdong Province, China. The study is first contextualized within the larger framework of course evaluation and is placed within the realm of narrow, formative assessments. Afterwards, the core principles of Hirvela's work are identified. These principles are applied in step-by-step fashion to the chosen academic writing course, with successes and lack of successes of the course being acknowledged. The paper then concludes by providing an overall picture of the usefulness of Hirvela's principles in evaluating academic writing courses. The significance of institutional and cultural environments is emphasized.
\end{abstract}

\section{Keywords}

Academic Writing, Course Evaluation, Curriculum Evaluation, Knowledge Construction, Reading/Writing Connections, Text-Responsible Prose

\section{Introduction}

In the well-known academic writing text They Sayl I Say. The Moves That Matter in Academic Writing, Graff and Birkenstein (2018) makes the following comment: "If it weren't for other people and our need to challenge, agree with, or otherwise respond to them, there would be no need to respond to them at all" ( $\mathrm{p}$. 4). This straightforward comment highlights the importance of reading/writing 
connections in academic writing courses. Student writers need to be constantly in dialogue with other texts in order to produce their own academically relevant texts. This dialogue requires a clear understanding of other texts, an application of those texts to the particular writing task, and a transformation of those texts in such a way as to allow the writer him/herself to engage in his/her own process of meaning-making (see Wette, 2010). Ultimately, then, the final product of student work will inevitably be the "joint effort of a group of people" (Zhang, Sheng, \& Li, 2014: p. 98). Such a “joint effort" calls for an ability to produce "text-responsible prose" in a manner acceptable to the academic community outside of the learners' particular writing classes (see Leki \& Carson, 1997: p. 63). As $\mathrm{Gu}$ and Brooks (2008) point out, this effort requires "a conceptual understanding of knowledge construction and conventions in the dominant academic community" (p. 338, italics as in original).

L2 writers, grappling with a new linguistic code and a new system of conveying knowledge, must take additional steps to reach the conceptual level required of academic writing tasks. Summary writing, for example, may pose problems. Dovey (2010) reported on a study in which learners in the early stages of their academic writing development lacked an "overarching purpose" for their summaries (p. 51). If the task of summary writing creates obstacles for L2 writers, it is not surprising that higher-order academic writing skills are also found to be lacking. Huang (2010) noted that instructors of graduate programs at a university in Canada identified paraphrasing and the ability to "use sources appropriately to support and refine arguments" as areas in which L2 writers needed significant improvement (p. 529). Unfortunately, L2 writers' limitations in the production of "text-responsible prose" appropriate to the target academic community have led to frequent accusations of plagiarism even though the core issue may be more related to matters involving L2 writers' development of the skills of appropriate source use-that is, to matters of reading/writing connections (see Keck, 2014). And McCulloch (2013) observes that less experienced L2 writers are unable to comment on the content of sources, pay little attention to the credibility of sources, and make few connections between one source and another. Writing problems, then, may ultimately be traced to reading problems or, more specifically, to problems of composing source-based texts (see Hirvela, 2016).

Given the significance of reading/writing connections for success in L2 academic writing, this paper presents a study in which the main principles of Hirvela's (2016) second edition of Connecting Reading and Writing in Second Language Instruction are considered as a tool for evaluating academic writing courses intended for second language writers (L2 writers). The paper does not present Hirvela's text as the only tool to be taken into account in the evaluation of academic writing courses. Instead, by applying Hirvela's main principles to a previously designed academic writing course, it seeks to examine the ways in which these principles may help to indicate areas for the improvement of academic writing courses-particularly, those areas related to reading/writing connections. 


\section{Literature Review: Evaluating Courses}

\subsection{Overview}

The literature related to the evaluation of academic writing courses tends to meld the terms course, curriculum, and program. Nation and Macalister (2010) note that the evaluation component of the "curriculum design process is to decide how to check if the course is successful and where it needs to be improved" (p. 123). In the chapter "Approaches to evaluation," Richards (2001) sometimes refers to course and sometimes to program. He also defines the "second language curriculum" as an "interlinked system of elements" that includes "needs, goals, teachers, learners, syllabuses, materials, and teaching" (p. 286, italics mine). Taking into account this "interlinked system of elements," the present discussion will operationalize the term curriculum as the curriculum of any particular academic writing course while acknowledging the fact that the term curriculum may also refer to an entire sequential program of study undertaken over a series of courses.

\subsection{Broad and Narrow Evaluations}

Nunan (1988) divides the curriculum into three components: the planned curriculum, the implemented curriculum, and the assessed curriculum. The planned curriculum, as the term suggests, consists of the formal documents stating what is expected to happen in a course. The implemented curriculum refers to what instructors and students actually do in the classroom. And the assessed curriculum relates to what learners actually learn in a course. Nunan (1998) is quick to point out that it would be "hopelessly naïve" to think that the three are identical as there is substantial evidence indicating that what is planned is not necessarily taught and what is taught is not necessarily learned (p. 136; see also Levine, 2002). Given the difference among the three types of curriculum, Nunan (1988) proposes that all three be taken into account in curriculum evaluation.

Nation and Macalister (2010), while recognizing the value of the "broadest kind of evaluation," note that most evaluations involve more narrowly focused aspects of the curriculum (p. 123). The authors provide sample evaluative questions, among which are the following:

- Is the teaching on the course of a suitably high level?

- Are the learners satisfied with the course?

- Is the course cost effective?" (Nation \& Macalister, 2010: p. 123).

Richards (2001) seems to concur with the notion that course evaluations tend to have specific foci. Among the possible foci that he mentions are the following:

- curriculum design: to provide insights about the quality of the program planning and organization

- the syllabus and program content: for example, how relevant and engaging it was, how easy or difficult, how successful tests and assessment procedures were

- materials of instruction: to provide insights about whether specific materials are aiding student learning" (Richards, 2001: pp. 286-287, italics as in original). 


\subsection{Formative and Summative Evaluations}

Nation and Macalister (2010) define a formative course evaluation as one which "has the purpose of forming or shaping a course to improve it" (p. 125). Richards (2001) echoes this sentiment by defining formative evaluation as a focus on "ongoing development and improvement of the program" (p. 288). His list of typical questions related to such evaluation includes the following:

- Has enough time been spent on particular objectives?

- Are students getting sufficient practice work?

- Is the pacing of the material adequate?" (Richards, 2001: p. 288).

Nation and Macalister (2010) define a summative course evaluation as one which "has the purpose of making a summary or judgement on the quality or adequacy of the course so that it can be compared with other courses, compared with previous summative evaluations, or judged as being up to a certain criterion or not" (pp. 125-126). Richards (2001) provides a similar definition while noting that summative evaluation is related to the "acceptability" of a course (p. 292). According to Richards (2001), possible questions to be asked in summative evaluation are the following:

- How effective was the course? Did it achieve its aims?

- What did the students learn?

- How appropriate were the teaching methods?" (p. 292).

The above-mentioned distinction between formative and summative evaluation is a bit vague.

There is no obvious reason to think that a question such as "Has enough time been spent on particular objectives?" relates more to formative evaluation than to summative evaluation. While the questions provided in the relevant literature may not lead to a key distinction between the terms, one may surmise that the distinction lies principally in the degree of finality of the evaluation. Clarifying the matter, Long (1984) stresses that formative evaluation deals more with attempts to modify a course whereas summative evaluation "is usually to determine whether or not the program should be continued" (p. 417).

\subsection{Evaluation Terminology and the Current Study}

The terminology given above aims simply to put the present study into its relevant context. A consideration of Hirvela's (2016) analysis of reading/writing connections in the evaluation of academic writing courses requires a clear placement of Hirvela's (2016) work within the broad context of course/curriculum evaluation: Hirvela's (2016) work is used here to provide a narrow course assessment tool for formative, definitely not summative, course evaluations.

\section{The Study}

\subsection{Procedures}

The study provided here consists of a close analysis of Hirvela's (2016) reading/writing connections as they relate to a previously designed academic writing 
course. It is based on the notion, mentioned above, that the production of "text-responsible prose" depends largely on students' understanding of the ways in which knowledge is constructed within the larger academic community outside of their own writing courses. The development of this understanding requires writing courses that lead L2 learners toward a clear conception of the reading/writing connections on which academic writing is based.

The starting point for such research consisted simply of identifying the key principles in Hirvela's (2016) work. Granted, such identification was somewhat subjective. The identification of "key principles" necessarily required some judgements to be made on the part of the present author. Though research concerning L2 reading/writing connections is certainly indebted to similar work regarding L1 writers (i.e., writers writing in their native language), Hirvela's (2016) discussion of L1 research was not considered "key" simply because of the additional difficulties faced by L2 writers (see Ferris, 2009; Grabe \& Zhang, 2013). As Hyland (2016) noted, L2 writers "are likely to operate with very different schemata to first-language writers and have very different conceptions of rhetorical patterns" (p. 237). Curiously enough, the unquestionably important issue of assessing student writing was also not considered "key". The omission of this item here stems from the fact that assessment is not a key element in Hirvela's (2016) discussion. Hirvela (2016: p. 129) himself notes that the "book is not about the assessment of writing".

After the exclusion of L1-related research and assessment (for the reasons mentioned above), "key principles" were chosen. These principles were identified as the following:

- general principles of reading/writing connections;

- knowledge telling vs. knowledge transforming;

- reading for writing/writing for reading;

- integration of reading and writing along a continuum;

- pedagogy as it concerns reading/writing connections.

\subsection{The Course}

The academic writing course chosen for purposes of this study is one which was initially designed for the Spring Semester of the 2015-2016 academic year in the English Language Center (ELC) of Shantou University (STU), a key provincial institution located in Guangdong Province, China. It subsequently underwent a rather large transformation for the 2016-2017 academic year. The transformed version serves as the base for the current study as it stands as the one that was taught several times before the undertaking of the study. Admittedly, a practical reason for the choice of this particular course is that the author of the present paper was the main course designer and therefore feels entitled to compliment/criticize it freely.

The course, conveniently labeled ELC-5, was an elective course designed for undergraduate, primarily non-English major students at STU. Students taking 
the course had completed, as a prerequisite, a four-semester program consisting of courses appropriately labeled ELC-1, ELC-2, ELC-3, and ELC-4, with each course consisting of 16 weeks of study. The last course in the required sequence, ELC-4, stood out as being the one that specifically required source-based writing-that is, writing requiring "text-responsible prose." Hence, students undertaking study in ELC-5 had already been exposed to the basics of source-based writing and were intending to enhance their skills in this area. The intended learning outcomes (ILOs) of ELC-5 were stated as follows:

$\diamond$ By the end of the course, the student will be able to:

$\checkmark$ effectively describe and write about a city problem of your choice (as evidenced by the Problem-Solution Essay assignment).

$\checkmark$ conduct research on a topic of his/her choice (as evidenced by the Argumentative Research Paper assignment).

$\checkmark$ summarize, paraphrase, and effectively synthesize research (as evidenced by the Argumentative Research Paper assignment).

$\checkmark$ orally present the primary argument of a research paper and answer related rebuttal questions (as evidenced by end-of semester Argumentative Oral Presentations).

$\checkmark$ carry out the steps of the writing process (as evidenced by the Freewriting Journal and Ongoing Process Writing throughout the semester).

$\checkmark$ identify and correct mechanical errors in written work (as evidenced by Peer Revisions).

$\checkmark$ analyze and discuss scholarly research (as evidenced by ongoing Discussion \& Analysis of Scholarly Articles).

$\checkmark$ use critical thinking skills to research and design writing for their community (as evidenced by the Writing to Enhance the Community Project assignment).

$\checkmark$ use writing for useful and practical purposes outside of the classroom (as evidenced by All Course Assignments).

\subsection{Research Questions}

As mentioned above, discrepancies are bound to exist among what is planned, what is taught, and what is learned. Clearly, the previously stated ILOs indicate what was planned for the course-that is, the planned curriculum in Nunan's (1988) terms. The assessed curriculum, in Nunan's (1988) terms, ultimately takes a deterministic approach which assumes that a curriculum/course may be evaluated by considering students' scores in a preconceived ranking scheme. Such is not the aim of the present paper. As this paper focuses on formative evaluation (see Section 2.4), the research questions provided below relate to the planned curriculum of ELC-5 as it was carried out in the implemented curriculum (i.e., what teachers and students actually did in the course) (see Nunan, 1988). Hence, they take into account not only the ILOs stated above but also specific course practices. The research questions, then, are intended to lead to insights into the degree to which the ILOs, as carried out in actual coursework, made use of the principles concerning reading/writing connections specified in Hirvela (2016). 
The research questions guiding the study were as follows:

1) To what degree does an existing academic writing course implement Hirvela's (2016) main principles concerning reading/writing connections?

2) To what degree does an existing academic writing course fall short in implementing Hirvela's (2016) main principles concerning reading/writing connections?

3) To what degree do Hirvela's (2016) main principles concerning reading/writing connections serve as a tool for the evaluation of academic writing courses?

\section{Analysis and Discussion}

\subsection{General Principles of Reading/Writing Connections}

Hirvela's (2016) basic principles for implementing reading/writing connections in writing instruction include the following:

- Because reading provides a vital source of linguistic and rhetorical input for writing, writing assignments should start in acts of reading and be sustained and informed by acts of reading.

- Writing assignments involving reading and writing about more than one source text provide richer content for linking the acts of reading and writing than do those involving a single text.

- Writing and reading tasks are more meaningful for students ... when they're linked to the literacy requirements students perform in other settings, such as other courses of out-of-school locations.

- Students should be given opportunities to talk about their encounters with reading and writing, and not just read and write.

- Reading and writing should be presented as recursive in nature-that is, as activities involving back-and-forth movement between them-as this is the kind of perspective that helps link them (pp. 32-33, italics as in original).

There can be little doubt that the ELC-5 course adhered to the general principles described in Hirvela (2016). Preceding the problem-solution essay assignment concerning city improvement was a jigsaw task in which different groups of students became "experts" in different city-improvement plans and needed to share their expertise with non-expert classmates. In this way, readings served to "provide a stimulus to writing" and at the same time provided useful models of linguistic input (Hyland, 2013: p. 391). As for the number of texts used in assignments, students were expected to use at least five academic sources in their research paper assignment. Hence, L2 writers were encouraged to "find a way of entering into conversation with the views of others" (Graff \& Birkenstein, 2018: p. 4). The writing to enhance the community project led students to seek a multimodal form of source use, with published photographs and recorded interviews often serving as key sources. The project, then, advocated a flexible approach to source use that allowed learners to develop the multimodal literacies that now compete with traditional print literacies (see Hirvela, 2016; Van Leeuwen, 2015). 
The ELC- 5 course tackled the matter of having L2 writers talk about reading/writing connections and that of making writing relevant outside of the writing class in various ways. Peer review, a standard "formative developmental process" (Hyland, 2006: p. 104), was used throughout the course. Students were encouraged to choose a research-paper topic related to their field of study and to pursue this research for their undergraduate thesis requirements. They were therefore encouraged to focus their work "on topics more central to their academic and intellectual lives" (Leki \& Carson, 1994: p. 93). Perhaps more significant in terms of promoting talk and relevance was the implementation of a technique involving research partners-a technique which asked learners with similar interests to share research findings and to work collaboratively even when producing individual work. The research paper assignment, for example, came with the following instruction: "In order to facilitate the research process, you will work with one partner (i.e., your research partner). You and your partner will be encouraged to share ideas and to share research. However, you will write separate research papers." The norm for the research partner technique was fairly simple: no work got to the course instructor without first being viewed and assessed by the research partner; instead of individual conferences to discuss drafts and/or components of the research paper, pair conferences were held. Such pairwork allowed for a large degree of peer scaffolding, the process through which learners produce work beyond the capability of any one individual (see Lantolf \& Thorne, 2006). It also called for a constant re-negotiation of reading/writing connections as partners shared academic texts and discussed how the texts might be used in their work.

\subsection{Knowledge Telling vs. Knowledge Transforming}

Bereiter and Scardamalia (1987) coined the terms knowledge telling and knowledge transforming in their seminal work The Psychology of Written Composition. Hirvela (2016) distinguishes the terms as follows: "Knowledge telling is when writers focus on displaying their understanding of what they've read, such as in a summary, by restating its content; knowledge transforming involves producing a new text that presents what was read in a new light" (p. 35, italics as in original). Hyland (2003) presents the terms specifically as they relate to L2 writers. Less experienced L2 writers, according to Hyland (2003), engage in limited planning, limited revision, and mainly focus on completing writing tasks-that is, they focus on knowledge telling. More experienced L2 writers engage in more revision and reflection and ultimately strive to present original ideas-that is, they focus on knowledge transforming. Hirvela (2016) notes that "an EAP writing course might feature a sequence of writing tasks in which students begin with knowledge telling in the form of summary writing and eventually move to the more ambitious knowledge transforming, as reflected in synthesis writing" (p. 36).

The ELC-5 course may be said to have led students through the process from knowledge telling to knowledge transforming. To begin their work with basic 
summary writing, learners were given two rather simple texts, one about the role of women in traditional Korean society, one about the problems associated with the proliferation of cell phones in American public schools. They were asked to provide summaries of the short texts and were instructed to keep in mind basic matters of who, what, where, when, and why. After a peer review session, successful summaries were shared with the class and applauded in keeping with Dörnyei's (2001) view that "praise may increase learner satisfaction and lift the learning spirit" (p. 123). As the text dealing with cell phones in American schools also dealt with issues of violence in American schools, it served as a bridge to a more challenging task involving summarizing, paraphrasing, synthesizing, and the L2 writers' own opinions. After receiving instruction concerning paraphrasing and synthesizing, students worked in trios to complete a jigsaw task consisting of three texts related to the causes of crime. They then completed a practice writing exercise in which, individually, they used information from the three texts to provide their own opinions concerning the causes of crime. Such a series of tasks called for increasing engagement with source texts and led learners to interact more critically with the texts as they engaged in their own knowledge construction.

\subsection{Reading for Writing/Writing for Reading}

Hirvela (2016) divided reading for writing into two categories-one dealing with reading to "gain knowledge about a topic in order to write about it," the other with reading "to learn about writing" (p. 37, italics as in original). What Hyland (2013) refers to as "stimulus materials" would seem to fall into the first category (p. 393). These may include standard written texts, videos, or screen-based materials that "provoke ideas" and lead learners to "articulate their thoughts" (p. 393). In terms of materials "to learn about writing," model texts are frequently used. These texts serve as materials to help familiarize learners with particular features of academic writing-especially with the genre in which they are expected to write (Hyland, 2008). In this way, such texts provide learners with "socially situated attempts to communicate with readers" and thus help to equip them with the standard tools for knowledge construction used in particular disciplines (Hyland, 2008: p. 543).

A consideration of the ELC- 5 course suggests that the course sufficiently engaged learners in reading for writing practice. The use of "stimulus materials" in ELC- 5 has been discussed in terms of the learners' preparation for a problem-solution essay revolving around city improvement (see Section 4.1). Such materials were also employed in instruction concerning the use of paraphrasing and synthesizing skills in the production of a knowledge transforming text (see Section 4.2). The use of models (i.e., texts for learning about writing) in ELC-5 necessarily had to take the rather general approach of an English for Academic Purposes (EAP) course as opposed to the specific approach of an English for Specific Purposes (ESP) course since students were from a variety of academic disciplines. In other words, model texts could not represent all possible academic 
disciplines in which the learners might write. Nevertheless, as $\mathrm{Hu}$ (2007) notes, academic writing across disciplines does reveal similarities in spite of the obvious differences. Given time limitations, one model essay was chosen for analysis for each writing assignment, yet other models were made available to students on the class Moodle page. In short, feasibility issues dictated the use of models and limited the inclusion of the genre-specific type of models that would have been desirable under ideal circumstances.

Compared to the reading for writing literature, the available literature concerning writing for reading would have to be considered scarce. Hirvela (2016) notes the following: "[I]t could be said that in contemporary reading-writing connections scholarship, source-based writing and reading for writing are essentially synonymous with each other" (p. 47). Relevant writing for reading publications have tended to focus on reading strategies employed by L2 writers in EAP settings. Baker and Boonkit (2004) used Oxford's (1990) taxonomy of learning strategies in an investigation of the reading strategies employed by Thai learners. The results revealed that learners making greater use of their L2 (English) were generally more successful in their academic writing tasks than were those who relied more heavily on their L1 (Thai). Plakans (2009), in reporting on a study conducted at two American universities, also focused on reading strategies and found that the following strategies were particularly important for L2 writers engaged in reading/writing integrated tasks: “(a) goal-setting for reading the source texts, (b) cognitive processing, (c) global strategies, (d) metacognitive strategies, and (e) mining the source texts for use in writing" (p. 256). She concluded that "reading is especially important in prewriting" (p. 261).

The ELC-5 course would have to be considered as coming up short in terms of establishing writing for reading connections. A fairly short text, "InnovationEngineering a Better Engineer for Today's Workforce” (Galloway, 2004), was used to provide instruction in reading strategies. The straightforward nature of the article along with its focus on the topic of education (a topic accessible to all students) made it appropriate for a lesson on reading strategies (e.g., predicting content, skimming and scanning, guessing meaning from context). Such a lesson might be considered an introduction to writing for reading but should not be considered an end in itself. Hirvela (2016) points out that, in order to encourage writing for reading, instructors could ask learners to "write summaries or annotations of sources they've read," and he goes on to mention the skill of note-taking (p. 37). The summary-writing tasks used in the course (see Section 4.2) were intended mainly to promote reading for writing connections, not writing for reading connections. And though a template for an annotated bibliography was provided for students at the beginning of the course, there was no ongoing effort to promote the skills of annotation or note-taking. Again, the ELC-5 fell short in aiding learners in the establishment of writing for reading connections.

\subsection{Integration of Reading and Writing along a Continuum}

Hirvela (2016) makes his most basic claim regarding the development of learn- 
ers' ability to integrate reading and writing by noting that students can be led to proceed from basic summary writing to synthesizing and then to a research paper task. The research paper task, according to Hirvela (2016), "requires summarizing and synthesizing as well as other academic skills essential in the acquisition of a proficiency in academic literacy" (p. 67). Then, citing Perkins and Salomon (1992), Hirvela (2016) distinguishes between near transfer and far transfer, with the former consisting of instructional situations in which there is little difference between one task and another and the latter of instructional situations in which there is considerable difference between tasks therefore a larger gap for learners to fill. While far transfer may be said to take place within a single course (e.g., through the movement from basic summary writing to research-paper writing), the ideal of far transfer takes place when "students acquire reading-writing skills that they can apply, or transfer, to future source-based writing contexts beyond the writing course" (Hirvela, 2016: p. 90). Though transfer "beyond the writing course" is hard to guarantee, conditions may be established to promote it.

In the ELC- 5 course, efforts to promote near and far transfer along a continuum have been discussed in terms of movement from basic summaries to larger tasks requiring summarizing, paraphrasing, and synthesizing in order to produce original, knowledge-transforming texts (see Section 4.2). Also, as mentioned previously (Section 4.1), students were encouraged to use their research paper as a bridge toward completing their required undergraduate thesis. Perhaps the biggest step toward promoting transfer "beyond the writing course," however, came in the writing to enhance the community project. This assignment, while requiring the making of reading/writing connections, also promoted a consideration of audience beyond the classroom. One student's work consisted of an introduction to Shantou for non-Chinese people. Using academic texts, published photographs, personally taken photographs, and interviews, the student undertaking the task implemented a multimodal approach to reading/writing connections in a laudable effort to construct knowledge on her chosen topic. Another student's work consisted of a survey of package-delivery methods used on university campuses in China, with the goal being to improve Shantou University's own method of package delivery. Such work, though carried out initially to complete a course assignment, would seem to suggest that the project indeed prompted learners to apply reading/writing connections for purposes beyond the writing classroom.

\subsection{Pedagogy as It Concerns Reading/Writing Connections}

In terms of pedagogy, Hirvela (2016) discusses five models: the multimodal model, the literature-based model, the collaborative model, the content-based model, the sequential model. An in-depth discussion of each model would certainly be beyond the scope of this paper. Hence, a short synopsis of each model will precede an analysis of the pedagogy guiding the ELC-5 course. 
- the multimodal model: takes into account modern technological developments and promotes a "hybrid notion of source text selection in the belief that students, as they move through the academic curriculum, will be expected to navigate a wide array of text types as readers and writers" (Hirvela, 2016: p. 133).

- the literature-based model: dismisses arguments that literature is often irrelevant to students' academic trajectories and argues that "literature provides meaningful content for students to write about” (Hirvela, 2016: p. 144).

- the collaborative model: links speech and writing, promotes peer scaffolding, encourages the type of negotiation commonly required in academic circles.

- the content-based model: links reading and writing with the goal of promoting reading/writing connections in "writing-related tasks students perform in other courses" (Hirvela, 2016: p. 161).

- the sequential model: builds reading/writing connections by guiding learners through a developmental process in which one stage in the process builds on the previous one.

Clearly, the various models briefly described above are not mutually exclusive. The literature-based model, advocated by Tomlinson (2013) as one which promotes learners' affective involvement in learning and leads them to make use of multi-dimensional modes of thinking, was not used in the ELC-5 course. As the course was typically taken by non-English majors, a focus on literature was deemed, whether correctly or incorrectly, as being somewhat impractical for them. The other models described above were used to varying degrees: The multimodal model was implemented in the writing to enhance the community project; the collaborative model was thoroughly implemented throughout the course (e.g., peer review, research partners); the content-based model was implemented through the connection of learners' work with thesis requirements; and the sequential model was implemented through both near- and far-transfer tasks.

Such a blend of models could be said to constitute no model at all-that is, it could be viewed as a sort of random eclecticism at the expense of any principled approach (see Prabhu, 1990). However, as Hirvela (2016) makes clear, each of the described models has its advantages, all based on research findings. At the same time, each model could be criticized. Hyland (2006), for example, points out that peer review, a central component of the collaborative model, has been considered "inappropriate for learners from collectivist cultures" (p. 43). Although Chinese culture is traditionally considered to be collectivist (see Hofstede, Hofstede, \& Minkov, 2010), this concern was not viewed as being a major factor in the design of ELC-5 since STU students routinely engage in peer review in their English courses and are therefore quite accustomed to it. Ellis (2003) points out that the gradation of tasks, a central component of the sequential model, "cannot follow a precise algorithmic procedure but rather must proceed 
more intuitively in accordance with a general assessment of task complexity" (p. 227). This lack of scientific precision was not viewed as particularly limiting since the principal course designer (i.e., the author of this paper) and all instructors involved in teaching the course were well aware of the types of cognitive demands that could be placed on STU learners. The ELC-5 pedagogy, then, needed to be based on what Kumaravadivelu (2001) terms a "pedagogy of particularity" - a pedagogy "sensitive to a particular group of teachers teaching a particular group of learners pursuing a particular set of goals within a particular institutional context embedded in a particular sociocultural milieu" (p. 538). Within such a pedagogy, models must be transformed and perhaps blended to suit particular circumstances.

\section{Conclusion}

This paper has presented a method of applying the major principles of Hirvela's (2016) work to the evaluation of academic writing courses geared toward L2 learners. Course evaluation "can be neither simple nor uniform" (Levine, 2002: p. 1). Hence, the paper has presented the main points of Hirvela's (2016) work as one, but definitely not the only, tool to be used in the complex task of evaluating academic writing courses. Specifically, it has focused on the ways in which Hirvela's (2016) work may aid in evaluating and improving the essential reading/ writing connections needed for success in academic writing. The following concepts have been isolated for a narrow, formative evaluation of a previously designed academic writing course:

- general principles of reading/writing connections;

- knowledge telling vs. knowledge transforming;

- reading for writing/writing for reading;

- integration of reading and writing along a continuum;

- pedagogy as it concerns reading/writing connections.

The step-by-step consideration of these principles as they relate to a previously designed course has attempted to reveal ways in which course contents may be evaluated in accordance with the principles. It has shown that the course under consideration largely made use of the given principles for encouraging students to make reading/writing connections and thus to produce "text-responsible prose". Still, a major shortcoming in the course was found: The course emphasized reading for writing at the expense of writing for reading. The analysis conducted here suggests that any subsequent versions of the course would need to give more importance to the art of writing for reading. Also, the analysis has indicated that the ELC-5 course made use of a rather blended pedagogical model. Such a pedagogical blend is not new to academic writing courses (see, for example, $\mathrm{Hu}, 2007)$. The analysis here suggests that a choice of pedagogical model must take into account institutional and cultural realities and thus cannot be easily prescribed.

Regardless of the pedagogical model chosen, the current study reveals clear 
implications for the evaluation of academic writing courses. In early research concerning L2 learners' academic needs, both Ostler (1980) and Johns (1981) pointed to the ability to read academic texts as the most critical factor underlying students' success. Such an estimation of the importance of reading came from students (see Ostler, 1980) and from faculty members (see Johns, 1981). Some 30 years later, Davis (2013) questioned the ability of English for Academic Purposes (EAP) programs to provide students with the necessary skills for writing from sources. As indicated in the introduction of this paper, L2 writing difficulties often stem from L2 reading difficulties. Hence, writing difficulties may be resolved only through a recognition of the bi-directional nature of reading and writing - a recognition that reading skills and writing skills combine in the "joint effort” required of high-quality student writing. A consideration of reading/writing connections in course evaluation, then, would seem to position the two skills as equal partners joining forces to aid students along their academic path.

As Nation and Macalister (2010) note, course evaluation "allows for the adjustment of a course to a changing environment and changing needs" (p. 134). The significance of reading/writing connections in academic writing courses would seem likely to stand the test of time-through "the changing environment and changing needs" may very well lead to a greater focus on a multimodal approach to reading/writing connections. A flexible adoption of Hirvela's (2016) main principles as a tool for course evaluation would thus appear to be applicable to existing academic writing courses and to those currently being designed. Institutional and cultural contextualization of these principles will no doubt be necessary-as will the ongoing search for additional tools for the complex task of evaluating academic writing courses.

\section{Conflicts of Interest}

The author declares no conflicts of interest regarding the publication of this paper.

\section{References}

Baker, W., \& Boonkit, K. (2004). Learning Strategies in Reading and Writing: EAP Contexts. RELC Journal, 35, 299-328. https://doi.org/10.1177/0033688205052143

Bereiter, C., \& Scardamalia, M. (1987). The Psychology of Written Composition. Mahwah, NJ: Erlbaum.

Davis, M. (2013). The Development of Source Use by International Postgraduate Students. Journal of English for Academic Purposes, 12, 125-135. https://doi.org/10.1016/j.jeap.2012.11.008

Dörnyei, Z. (2001). Motivational Strategies in the Language Classroom. Cambridge: Cambridge University Press. https://doi.org/10.1017/CBO9780511667343

Dovey, T. (2010). Facilitating Writing from Sources: A focus on Both Process and Product. Journal of English for Academic Purposes, 9, 45-60.

https://doi.org/10.1016/j.jeap.2009.11.005 
Ellis, R. (2003). Task-Based Language Learning and Teaching. Oxford: Oxford University Press.

Ferris, D. R. (2009). Teaching College Writing to Diverse Student Populations. Ann Arbor, MI: The University of Michigan Press. https://doi.org/10.3998/mpub.263445

Galloway, P. D. (2004). Innovation-Engineering a Better Engineer for Today's Workforce. Leadership and Management in Engineering, 4, 127-132. https://doi.org/10.1061/(ASCE)1532-6748(2004)4:4(127)

Grabe, W., \& Zhang, C. (2013). Reading and Writing Together: A Critical Component of English for Academic Purposes Teaching and Learning. TESOL Journal, 4, 9-24. https://doi.org/10.1002/tesj.65

Graff, G., \& Birkenstein, C. (2018). They Say/I Say: The Moves That Matter in Academic Writing (4th ed.). New York: WW Norton \& Company.

Gu, Q., \& Brooks, J. (2008). Beyond the Accusation of Plagiarism. System, 36, 337-352. https://doi.org/10.1016/j.system.2008.01.004

Hirvela, A. R. (2016). Connecting Reading and Writing in Second Language Writing Instruction (2nd ed.). Ann Arbor, MI: University of Michigan Press. https://doi.org/10.3998/mpub.8122864

Hofstede, G., Hofstede, G. J., \& Minkov, M. (2010). Cultures and Organizations: Software of the Mind (3rd ed.). New York: McGraw-Hill Education.

Hu, G. (2007). Developing an EAP Writing Course for Chinese ESL Students. RELC Journal, 38, 67-86. https://doi.org/10.1177/0033688206076160

Huang, L. S. (2010). Seeing Eye to Eye? The Academic Writing Needs of Graduate and Undergraduate Students from Students' and Instructors' Perspectives. Language Teaching Research, 14, 517-539. https://doi.org/10.1177/1362168810375372

Hyland, K. (2003). Second Language Writing. Cambridge: Cambridge University Press. https://doi.org/10.1017/CBO9780511667251

Hyland, K. (2006). English for Academic Purposes: An Advanced Resource Book. London: Routledge. https://doi.org/10.4324/9780203006603

Hyland, K. (2008). Genre and Academic Writing in the Disciplines. Language Teaching, 41, 543-562. https://doi.org/10.1017/S0261444808005235

Hyland, K. (2013). Materials for Developing Writing Skills. In B. Tomlinson (Ed.), Developing Materials for Language Teaching (2nd ed., pp. 391-405). London: Bloomsbury.

Hyland, K. (2016). Teaching and Researching Writing (3rd ed.). London: Routledge. https://doi.org/10.4324/9781315717203

Johns, A. M. (1981). Necessary English: A Faculty Survey. TESOL Quarterly, 15, 51-57. https://doi.org/10.2307/3586373

Keck, C. (2014). Copying, Paraphrasing, and Academic Writing Development: A Re-Examination of L1 and L2 Summarization Practices. Journal of Second Language Writing, 25, 4-22. https://doi.org/10.1016/j.jslw.2014.05.005

Kumaravadivelu, B. (2001). Toward a Post-Modern Pedagogy. TESOL Quarterly, 35, 537-560. https://doi.org/10.2307/3588427

Lantolf, J. P., \& Thorne, S. L. (2006). Sociocultural Theory and the Genesis of Second Language Development. Oxford: Oxford University Press.

Leki, I., \& Carson, J. (1997). “Completely Different Worlds": EAP and the Writing Experiences of ESL Students in University Courses. TESOL Quarterly, 31, 39-69.

https://doi.org/10.2307/3587974 
Leki, I., \& Carson, J. G. (1994). Students' Perceptions of EAP Writing Instruction and Writing Needs across the Disciplines. TESOL Quarterly, 28, 81-101. https://doi.org/10.2307/3587199

Levine, T. (2002). Stability and Change in Curriculum Evaluation. Studies in Educational Evaluation, 28, 1-33. https://doi.org/10.1016/S0191-491X(02)00010-X

Long, M. H. (1984). Process and Product in ESL Program Evaluation. TESOL Quarterly, 18, 409-425. https://doi.org/10.2307/3586712

McCulloch, S. (2013). Investigating the Reading-to-Write Processes and Source Use of L2 Postgraduate Students in Real-Life Academic Tasks: An Exploratory Study. Journal of English for Academic Purposes, 12, 136-147. https://doi.org/10.1016/j.jeap.2012.11.009

Nation, I. S. P., \& Macalister, J. (2010). Language Curriculum Design. New York: Routledge. https://doi.org/10.4324/9780203870730

Nunan, D. (1988). The Learner-Centred Curriculum. Cambridge: Cambridge University Press. https://doi.org/10.1017/CBO9781139524506

Ostler, S. E. (1980). A Survey of Academic Needs for Advanced ESL. TESOL Quarterly, 14, 489-502. https://doi.org/10.2307/3586237

Oxford, R. L. (1990). Language Learning Strategies: What Every Teacher Should Know. Manchester: Newbury House.

Perkins, D. N., \& Salomon, G. (1992). Transfer of Learning. In T. Husén, \& T. N. Postlethwaite (Eds.), The International Encyclopedia of Education (2nd ed., pp. 425-441). Oxford: Pergamon.

Plakans, L. (2009). The Role of Reading Strategies in Integrated L2 Writing Tasks. Journal of English for Academic Purposes, 8, 252-266.

https://doi.org/10.1016/j.jeap.2009.05.001

Prabhu, N. S. (1990). There Is No Best Method-Why? TESOL Quarterly, 24, 161-176. https://doi.org/10.2307/3586897

Richards, J. C. (2001). Curriculum Development in Language Teaching. Cambridge: Cambridge University Press. https://doi.org/10.1017/CBO9780511667220

Tomlinson, B. (2013). Developing Principled Frameworks for Materials Development. In B. Tomlinson (Ed.), Developing Materials for Language Teaching (2nd ed., pp. 95-118). London: Bloomsbury.

Van Leeuwen, T. (2015). Multimodality in Education: Some Directions and Some Questions. TESOL Quarterly, 49, 582-589. https://doi.org/10.1002/tesq.242

Wette, R. (2010). Evaluating Student Learning in a University-Level EAP Unit on Writing Using Sources. Journal of Second Language Writing, 19, 158-177. https://doi.org/10.1016/j.jslw.2010.06.002

Zhang, L., Sheng, Y., \& Li, L. (2014). Evaluating an Academic Writing Course Based on an Integrated Model. Journal of Asia TEFL, 11, 95-124. 